
\title{
Pulmoner Nokardiyozis
}

\author{
Pulmonary Nocardiosis in an Immunocompetent Patient
}

Mesut Subak, Mine Gayaf, Güneş Şenol, Işıl Karasu, Ayşe Özsöz

\section{Özet}

Akciğer nokardiyozisi, immün düşkün hastalarda görülen önemli bir fırsatçı enfeksiyondur. Bakterinin inhalasyonu sonrası gelişen; akut, subakut ve kronik hastalık olarak karşımıza çıkar. Hastalığın klinik ve radyolojik bulguları özgün olmadığı için tanı koymak güç olabilir. Bu nedenle de spesifik tedavisi olmasına rağmen mortalitesi yüksek bir enfeksiyondur. Olgumuz öksürük, kanlı balgam, ateş yüksekliği şikâyetleri ile başvurdu. Hastamızda herhangi bir immünsupresif hastalık ya da tedavi öyküsü yoktu. Pulmoner nokardiyazis olgusu nadir görülmesi ve tanı koymadaki zorluklar nedeni ile literatür eşliğinde sunulmaktadır.

Anahtar Sözcükler: Nokardiyozis, pnömoni, fırsatçı enfeksiyon.

\begin{abstract}
Pulmonary nocardiosis is an important opportunistic infection that seen in immunosuppressed patients. After inhalation of bacteria, acute, subacute, and chronic disease may occur. As there are no specific clinical and radiological findings, there may be some difficulties in its diagnosis. Because of this, although there is specific treatment, nocardiosis has a high rate of mortality. The patient presented with cough, high fever and hemoptysis. He had neither immunosuppressive disease nor immunosuppressive therapy background. A case with pulmonary nocardiosis presented here with the review of literature due to difficulties in diagnosing and rare occurrence.
\end{abstract}

Key words: Nocardiosis, pneumonia, oppurtunistic infection.

\footnotetext{
Dr. Suat Seren Göğüs Hastalıkları ve Cerrahisi Eğitim ve

Clinic of Pulmonary Diseases, Dr. Suat Seren Chest Diseases Araşıırma Hastanesi, Göğüs Hastalıkları Kliniği, İzmir and Thoracic Surgery Training Hospital, İzmir, Turkey
}

Submitted (Başvuru tarihi): 10.06.2013 Accepted (Kabul tarihi): 31.07 .2013

Correspondence (iletişim): Mesut Subak, Dr. Suat Seren Göğüs Hastalıkları ve Cerrahisi Eğitim ve Araştırma Hastanesi, Göğüs Hastalıkları Kliniği, İzmir

e-mail:mesutsubak@gmail.com 
Nocardia'lar, aerobik, Actinomycetes grubundan, mikroskobik incelemede gram-pozitif, filamentöz, tesbih tanesi dizisi görünümündedirler. Hücre duvarı tüberkülostearik asit, mezo-diaminopimelik asit, arabinoz, galaktoz ve mikolik asit içermektedir $(1,2)$. Bu nedenle zayıf aside dirençli boyalar ile boyanmaktadır. Nokardiyoz, Nocardia cinsi bakterilerin insanda hayatı tehdit eden, ancak oldukça nadir görülen enfeksiyöz bir hastalığıdır. Hastalık, özellikle immünsüpresif olgularda, mikroorganizmanın vücuda giriş yerine göre pulmoner nokardiyoz veya kütanöz enfeksiyon şeklinde ortaya çıkar. Pulmoner nokardiya enfeksiyonu bakterinin inhalasyonu sonrası gelişen, aku† subakut veya kronik, çoğunlukla subakut seyirli süpüratif bir enfeksiyondur. Akciğer nokardiyozisine neden olan en önemli türler Nocardia asteroides ve Nocardia abcessusitus'tur (3)

Hastalığın klinik ve radyolojik bulguları özgün olmadığından tanı koymak güç olabilir. Pulmoner nokardiyozda akciğer radyografisindeki bulgular; konsolidasyon, kavitasyon, nodül benzeri görünüm ve plevral efüzyonlar şeklindedir (4).

Biz, immün sistemi normal olan ve herhangi bir sebepten dolayı yakın zamanda immünsüpresif tedavi kullanmayan bir pulmoner Nocardia asteroides olgusunu bildirmekteyiz.

\section{OLGU}

Elli iki yaşındaki erkek hasta kliniğimize öksürük, kanlı balgam, ałeş yüksekliği yakınması ile başvurdu. On gündür yakınmaları olan hastaya başka bir merkez de bir hafta parenteral antibiyotik tedavisi uygulanmış, klinik ve radyolojik yanıt alınamaması üzerine hastanemize sevk edilmiş. Özgeçmişinde 30 paket yıl sigara haricinde bir özellik yoktu. Anamnezde torna işinde çalıştığını ve ortamın zaman zaman tozlu olduğunu belirten olgunun herhangi bir hastalık için sürekli kullandığı ilaç veya bitkisel kaynaklı ilaç yoktu. Fizik muayenede, genel durumu orta, ateşi $39^{\circ} \mathrm{C}$, solunum sayısı $20 / \mathrm{dk}$, arteriyel kan basıncı $110 / 80 \mathrm{mmHg}$ idi. Solunum sistemi muayenesinde, dinlemekle sağda alt zonda inspiratuvar raller duyuldu, diğer sistem muayeneleri doğaldı. Eritrosit sedimantasyon hızı 56 mm/saat; hemogramda beyaz küre 32,400 / $\mathrm{mm}^{3}, \mathrm{Hb}$ : 15,5 g/dL, Hct \%47,4 MCV $89 \mathrm{fl}$ saptandı. Biyokimyasal tetkikleri olağan sınırlarda idi. Hastanın bakılan immünglobulin ve kompleman düzeyleri normal sınırlardaydı. Yapılan solunum fonksiyon testinde, FEV 1: 3,12 L ve FEV1/FVC: \%87 saptandı ve obstrüktif hava yolu patolojisi saptanmadı. Balgam gram boyamada gram pozitif, dallanma eğilimi gösteren bakteriler görüldü, basiller zayıf aside dirençli olarak boyandı, kültürde Nocardia spp üredi. PA akciğer radyogramında sağ akciğer de üsł zonda daha yoğun izlenen, içinde hava bronkogramları görülen heterojen dansite artımı mevcuttu (Şekil 1). Olgunun toraks bilgisayarlı tomografisinde; mediastende en büyüğü 1,5 cm çapında çok sayıda lenf bezleri tespit edildi. Parankimde sağ üst lob posterior segmentte, sağ orta lobda ve daha belirgin olmak üzere sağ alt lobda konsolidasyon görünümü oluşturan peribronkovasküler infiltrasyon alanları vardı (Şekil 2). Hastanın gönderilen diğer balgam kültürlerinde üreme olmaması ve balgam örneklerinde asidorezistan boyamanın menfi gelmesi, klinik, radyolojik ve laboratuvar bulgularının eşliğinde Nocardia'ya bağlı akciğer infeksiyonu düşünüldü. Tanı sonrası hastaya enfeksiyon hastalıklarının önerisi ile 320 mg trimetoprim ve $1600 \mathrm{mg}$ sülfametoksazol oral tedavi başlandı, tedavinin 10. gününde kliniği düzeldi. PA akciğer grafisinde lezyonlarda gerileme görüldü, tedavinin 1 . ayında çekilen akciğer bilgisayarlı tomografisinde; mediastendeki lenf bezleri küçülmüş (Şekil 3), sağ akciğerdeki lezyonların azaldığı tespit edildi. Hastaya taburculuk sonrasında 2 ay daha oral tedaviye devam edildi. Tedavi sonunda radyolojik olarak tam yanıt alındı (Şekil 4 ve 5).

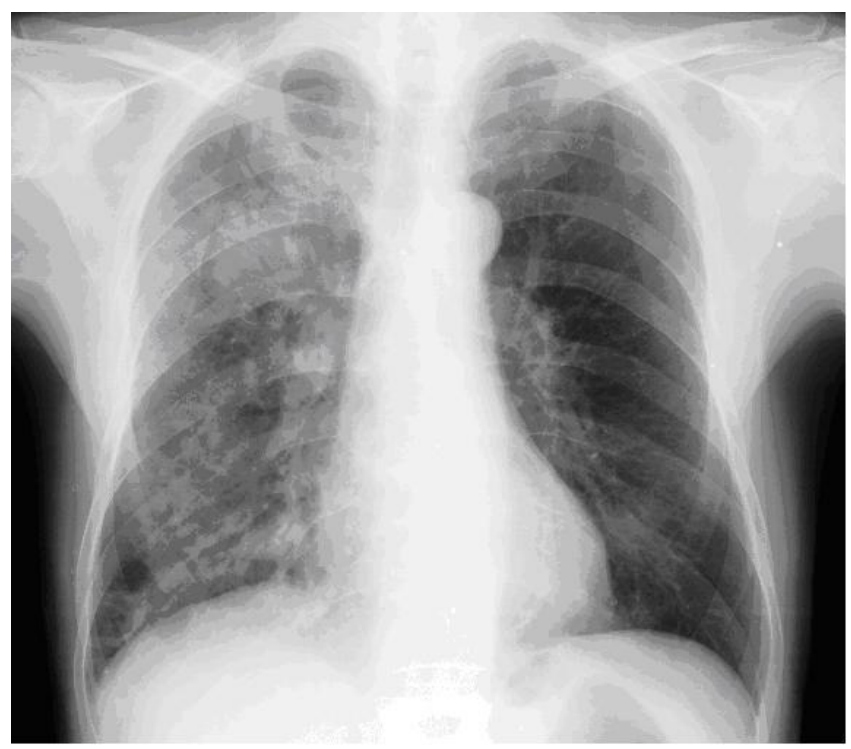

Şekil 1: Başvuru sırasındaki PA akciğer grafisi.

\section{TARTIŞMA}

Pulmoner nokardiyoz aerobik aktinomiçes grubundan nokardiyaların neden olduğu subakut veya kronik pnömonidir. Nokardiya grubunda 50'den fazla tür vardır. Pulmoner ve yaygın hastalık yapma potansiyeli en yüksek türler Nocardia asteroides ve Nocardia abcessus'tur.

Nokardiyozis ile ilgili pek çok ek hastalık bildirilmiştir. Özellikle immünitesi zayıflamış veya baskılanmış hastalıklar, örneğin solid organ transplant alıcıları, lösemili ve HIV enfekte hastalar, uzun süre kortikosteroid kullananlar 
(KOAH gibi) risk altındadırlar $(5,6)$. Nokardiya enfeksiyonuna karşı konağın direnci tamamen fagositik hücrelerin fonksiyonuna bağlıdır. Hücresel immünite nokardiya enfeksiyonunda çok önemlidir. Literatürde immün sistemi sağlam hastalarla ilgili nokardiya olgu serisi yoktur, tek olgu sunumları vardır. Ülkemizde immün sistemi normal olan bir olgu Karakan ve ark. (7) tarafından bildirilmiştir. Bizim olgumuzda da altta yatan immünsüpresyon durumu saptanmamıştır.
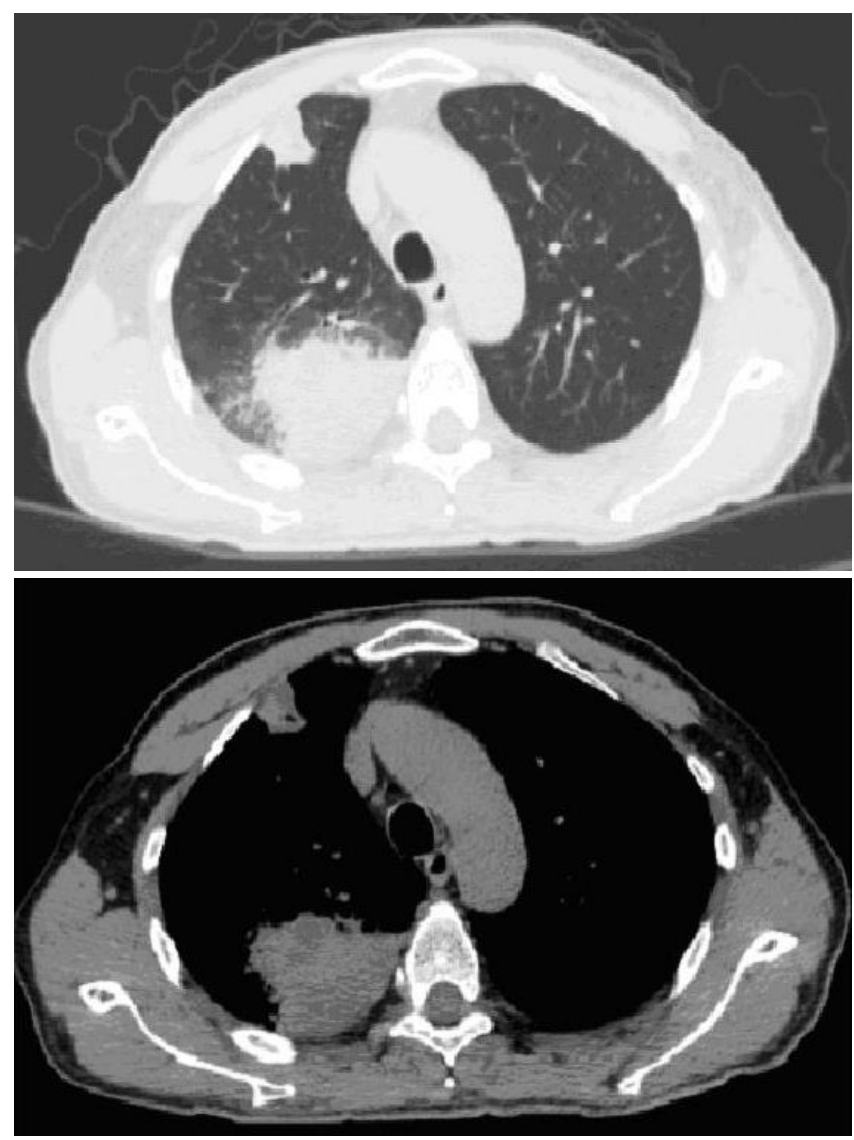

Şekil 2: Başvuru sırasındaki toraks tomografisi.

Pulmoner nokardiyoz kliniği, halsizlik ve yorgunluk gibi nonspesifik belirtilerden, solunum yetmezliğine kadar çok değişik tablolar ile kendisini gösterebilir. Aynı şekilde radyolojik bulguların da değişken olmasından dolayı hastalığın tanınması zordur ve bu durum tanı konulmasını güçleştirmektedir (8). Nokardiyozis tanısı bronş lavajı, balgam, apse aspirasyonu gibi klinik örneklerden organizmanın izole edilmesi ile konulur (2). Ancak burada klinisyen ile mikrobiyoloji laboratuvarının iletişim içinde olması gerekmektedir (5). Olgumuzda da gönderilen balgam örneğinde, organizmanın asidorezistan basil boyama pozitif, fakat zayıf asitlerle boyanması değerlendirilerek, etkenin Nocardia spp. olabileceği yönündeki uyarı tanı koymada önem taşımışıı. Nocardia türleri rutin mikrobiyoloji laboratuvarlarında kullanılan gerçek besiye- rinde rahatlıkla üreyebilmektedir. Üremeleri 3-5 gün arasındadır (9). Olgumuzun balgam direkt bakısında ve gram boyasındaki şüphe ile ampirik tedavi başlanması prognozu iyi yönde etkilemiştir. Nokardiya türleri normalde insan vücut sıvılarında yoktur, bu nedenle bu sıvılarda üremesi durumunda hastalık etkeni olarak kabul edilmesi ve tedaviye gecikmeden başlanması gereklidir. Tanı sonrası ilaç seçimi hastalığın ciddiyeti, ilaç toksisitesi ve hastanın durumuna bağlıdır. Sulfonamid (TMP/SMX) ilk tercih edilen antibiyotiktir. Amikasin ve Imipenem ise alternatif seçeneklerdir. Yaygın hastalık veya santral sinir sistemi tutulumunda tedavi kombine olarak ve 6-12 aya dek sürdürülmelidir (1 1). Bu olgumuzda TMP/SMX oral tedavisi ile klinik ve radyolojik yanıt aldık.

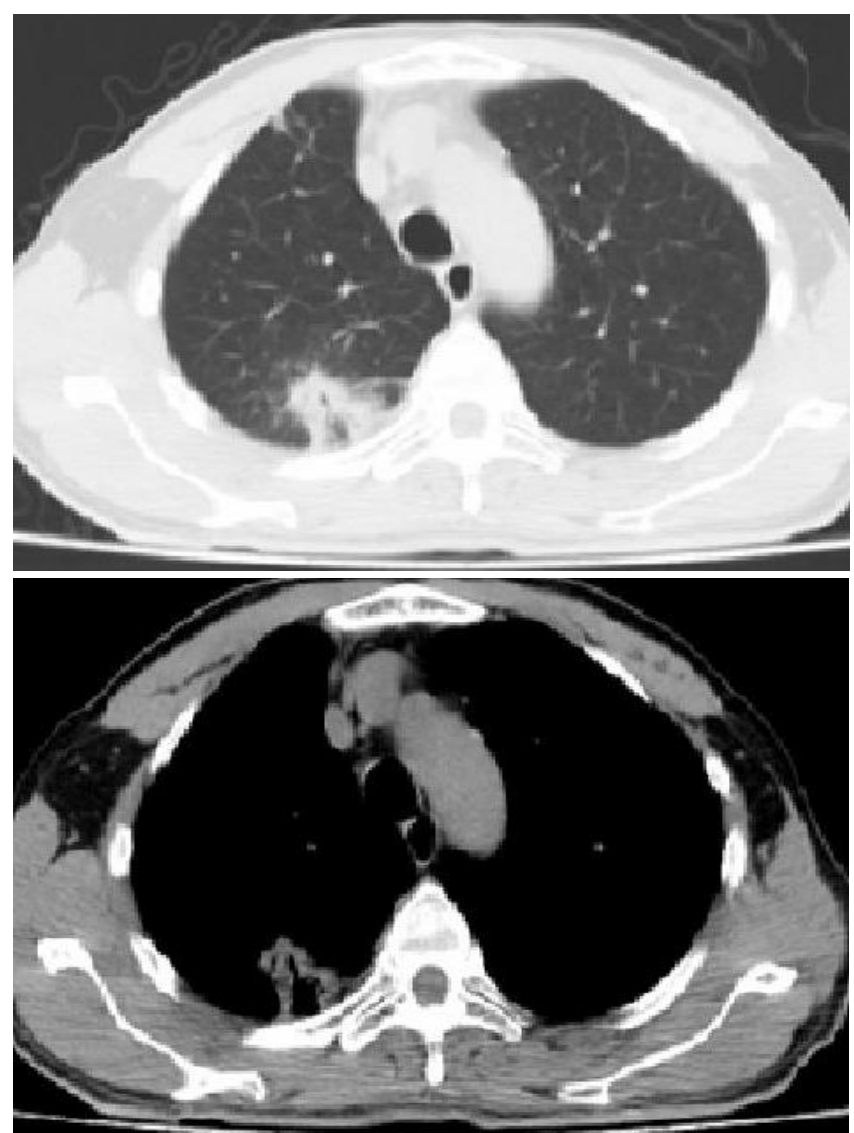

Şekil 3: Tedavinin birinci ayındaki toraks tomografisi.

Pulmoner nokardiyozis, kavitasyon, konsolidasyon (\%4070), plevral sıvı (\%36), nodüler görünüm (\%20) ve kitle lezyonu görünümü (\%20) şeklinde radyolojik bulgu verebilir (5). Hastalık daha çok üst lobda yerleşimli olduğundan direkt grafilerde tüberküloz ile karışmaya meyillidir (7). Bizim olgumuzda sağ üst lob posterior segmentte, sağ orta lobda ve sağ alt lobda tutulum mevcut idi. Yıldız ve ark.'nın (8) serilerinde, pulmoner nokardiyozlu üç hastanın ikisinde konsolidasyon alanları, birinde ise büyük pulmoner nodül şeklinde radyolojik bulgular tespit edil- 
miştir. Olgumuzda kavite görünümü yoktu, fakat peribronkovasküler infiltrasyon alanları mevcuttu; bu bilgiler de bizi daha çok tüberküloz ve bakteriyel pnömoninin ayırıcı tanıda düşünülmesine neden oldu. Hastadan alınan balgam örneğinin, rodamin ve EZN ile boyalı preparatlarında zayıf asidorezistan basil boyama pozitif olarak geldiği için kültür sonuçları görülünceye kadar anti tüberküloz ilaçlar başlanmamıştır. Tüberküloz kültürlerinde de üreme olmamışır. Benzer durumlarda Nokardiya'ya bağlı pulmoner enfeksiyonlar atipik mikobakterilerin akciğer tutulumu karışabilmektedir. Nocardia türleri ile olan akciğer enfeksiyonlarının, atipik mikobakteri enfeksiyonlarından ayırt edilmesi gereklidir. Genel klinik bulgular benzerdir. Laboratuvarda tanısal test aşamasında birbirlerine benzer özellikleri nedeniyle ayırt edilmeleri güç olabilir. Kültürdeki koloni yapıları ve bakterilerin morfolojik yapıları, mikrobiyolojik boyalarla boyanma özellikleri ortak noktalar içerir. Her iki tür de aside dirençli boyalarla boyanırlar. Bunun nedeni, Nocardia genusu hücre duvarı tüberkülostearik asit içermesi fakat Mycobacterium ailesindeki gibi bir mikolik asit içermemesidir. Bu nedenle aside dirençli boyalar ile boyanır ancak daha zayıf asitlere dirençlidir. Nocardia türleri rutin mikrobiyoloji laboratuvarlarında kullanılan birçok besiyerinde rahatlıkla üreyebilmektedir.
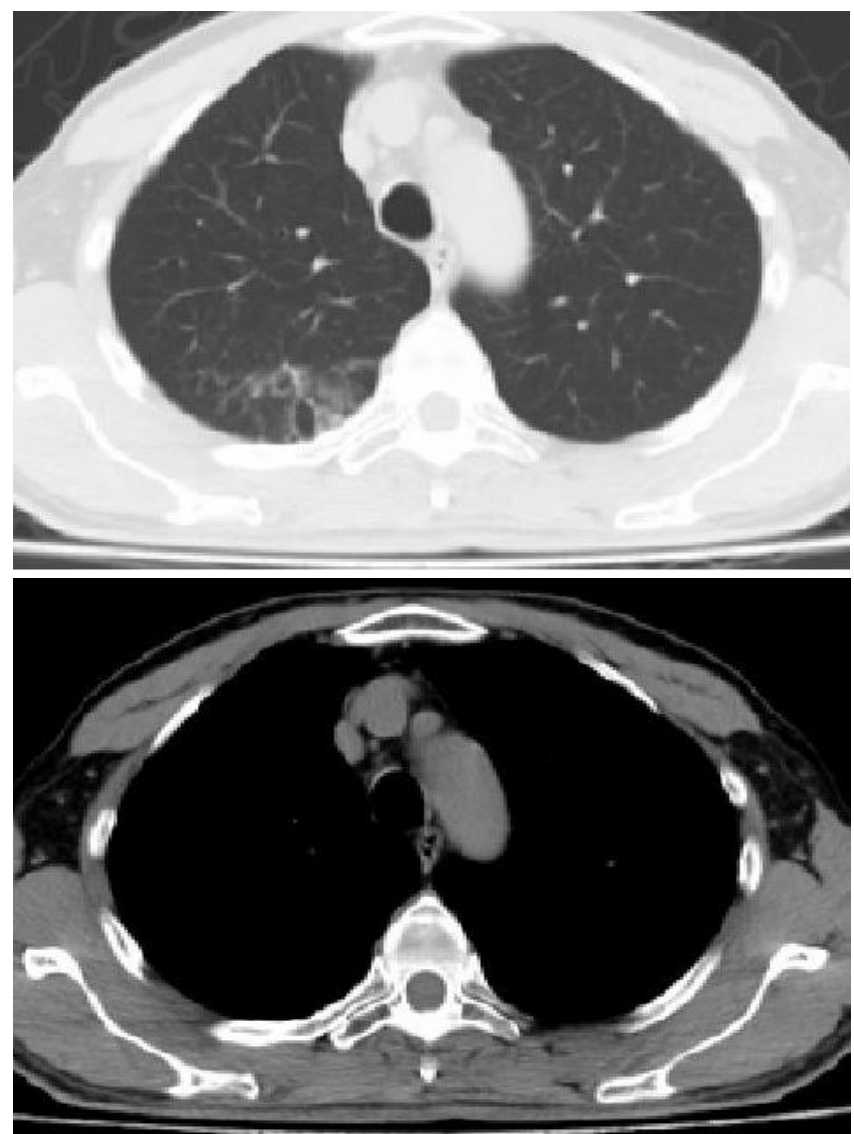

Şekil 4: Tedavi sonundaki toraks tomografisi.
Ayrıca Nocardia türleri mantar ve mikobakteri izolasyonu için kullanılan besiyerlerinde de ürerler (10). Kromotografik olarak mikolik asit analizi iki türün ayrılmasında yararlı bulunmuştur (11). Ayrıca PCR-RFLP yöntemi ile groEl geninin aranması, Nocardia türlerinin Mycobacterium türlerinden ayrıştırılmasındaki kesin yöntemlerden biridir (10).

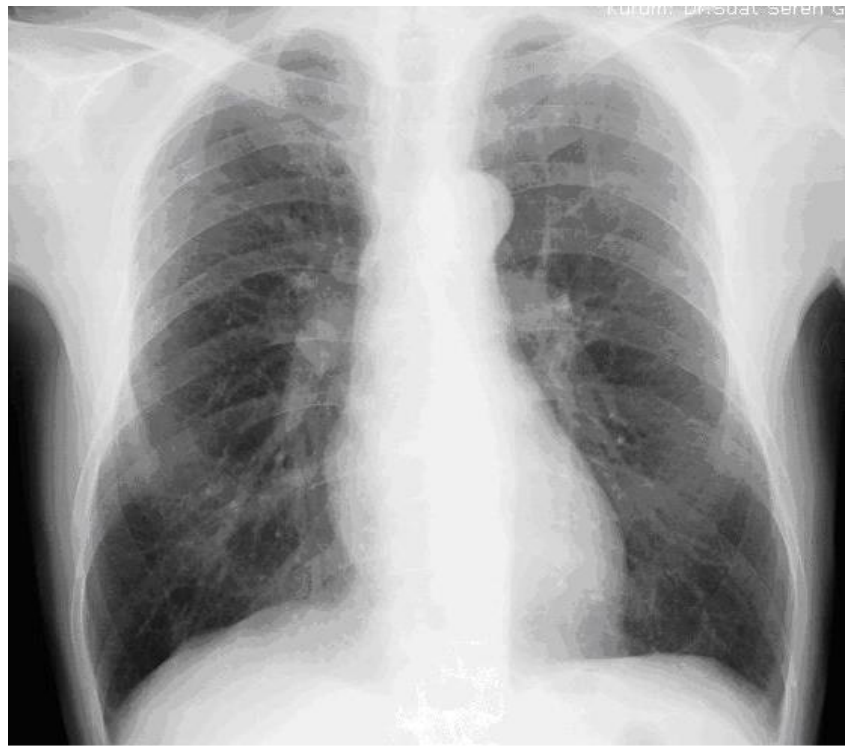

Şekil 5: Tedavi sonundaki PA akciğer grafisi.

Nokardia tedavisinde sülfonamidler sık kullanılan ve etkili ilaçlardır, fakat literatürde ancak imipenem, ampisilin ve minosiklin ile iyileşen olgular da bulunmaktadır (7). Genellikle üç-altı aylık bir tedavi süresi önerilmektedir. Bildirilen olguda da üç aylık bir tedavi sonrasında yapılan kontrollerde radyolojik bulgularında büyük oranda regresyon görülmüş ve tedavisine devam edilmiştir. Nüks ihtimaline karşı tedavi altı aya tamamlanmıştır.

Sonuç olarak, hücresel immünsüpresif hastalarda daha çok olmakla beraber, immün sistemi normal olan olgularda da rezolüsyonu gecikmiş konsolidasyonların pulmoner nokardiyozis açısından mutlaka değerlendirilmesi gerekmektedir.

\section{ÇIKAR ÇATIŞMASI}

Bu makalede herhangi bir çıkar çatışması bildirilmemiştir.

\section{YAZAR KATKILARI}

Fikir - M.S., A.Ö., M.G., G.Ş., I.K.; Tasarım ve Dizayn M.S., A.Ö., M.G., G.Ş., I.K.; Denetleme - M.S., A.Ö., M.G., G.Ş., I.K.; Kaynaklar - M.S., A.Ö.; Malzemeler A.Ö., M.S., G.S..; Veri Toplama ve/veya İşleme - A.Ö., I.K.; Analiz ve/veya Yorum - M.S., M.G.; Literatür Taraması - A.Ö.; Yazıyı Yazan - M.S.; Eleştirel İnceleme - A.Ö. 


\section{KAYNAKLAR}

1. Ekim N. Bakteriyel pnömoniler In: Ekim N, Ucan ES eds. Solunum sistemi infeksiyonları. İstanbul: Toraks Derneği; 2001:233-5.

2. Martinez R, Reyes S, Menendez R. Pulmonary nocardiosis: risk factors, clinical features, diagnosis and prognosis. Curr Opin Pulm Med 2008; 14: 219-27. [CrossRef]

3. Akbaş A, Seyhan EC, Sökücü SN, Alıın S, Günlüoğlu G, Altay S. Diyabetik hastada sistemik nokardiyoz. Respir Case Rep 2012; 1:37-41. [CrossRef]

4. Russo TA. Agents of Actinomycosis. In: Mandell GL, Bennet JE, Dolin R eds. Principles and Practice of Infectious Diseases. Sixth edition. Philadelphia: Churchill Livingstone; 2005:2924-34.

5. Ucgun I, Alataş F, Doğan B. Akciğer grafisinde kitle benzeri radyolojik görünüm yapan üç olgu nedeni ile akciğer nokardiyozisi üzerine genel bir değerlendirme. Klinik ve Deneysel Araştırmalar Dergisi 2010; 3:219-25.

6. Menendez R, Cordero PJ, Santos M, Gobernado M, Marco V. Pulmonary infection with Nocardia species: a report of 10 cases and review. Eur Respir J 1997; 10:1542-6. [CrossRef]
7. Karakan Y, Elbek $O$, Uyar M, Zer Y, Tulu M, Dikensoy $O$. Nocardia transvalensis infection in an immunocompetent patient reported from Turkey. Tuberk Toraks 2007; 55: 295-8.

8. Yıldız O, Alp E, Tokgöz B, Tucer B, Aygen B, Sumerkan B, et al. Nocardiosis in a teaching hospital in the Central Anatolia region of Turkey: treatment and outcome. Clin Microbiol Infect 2005; 11:495-9.

9. Lorner Pl, Diseases due to nocardia species. In: Mandell GL Benett SE, Dolin R (eds), Mandell, Dougas and Benett's Principles and Practise of infection Disease. NY: Churchill Livingstone; 1995:2273-80.

10. Brown-Elliott BA, Brown JM, Conville PS, Wallace RJ Jr. Clinical and laboratory features of the Nocardia spp. based on current molecular taxonomy. Clin Microbiol Rev 2006; 19:259-82. [CrossRef]

11. Asil el TA, El Sanousi SM, Mahgoub A, Aljameel MA, Terab NM, Abdellatif MM, et al. Chemical and biochemical profile of filamentous non-tuberculous mycobacteria isolated from caseous lesions in Sudan. $U$ of $\mathrm{K} \mathrm{J}$ Vet Med Anim Prod 2012; 3:54-68. 